\title{
Performance of Coffea arabica F1 hybrids in agroforestry and full-sun cropping systems in comparison with American pure line cultivars
}

\author{
B. Bertrand • E. Alpizar $\cdot$ L. Lara \\ R. SantaCreo $\cdot$ M. Hidalgo $\cdot$ J. M. Quijano $\cdot$ \\ C. Montagnon $\cdot$ F. Georget $\cdot$ H. Etienne
}

Received: 22 October 2010/Accepted: 25 January 2011/Published online: 16 February 2011

(C) The Author(s) 2011. This article is published with open access at Springerlink.com

\begin{abstract}
Coffea arabica F1 hybrids derived from crosses between wild Sudan-Ethiopian and American cultivars and propagated by somatic embryogenesis have been obtained in Central America. These new hybrids considerably enhanced the genetic diversity of coffee in the region. We conducted 15 trials to assess whether using hybrids represents substantial genetic progress in terms of productivity in agroforestry and full-sun cropping systems. The new germplasm was grown in the same conditions as the best American cultivar (homozygous pure lines). The results showed that yields of hybrids were earlier and superior to those of American cultivars. The hybrids were also more stable than the American cultivars in all environments.
\end{abstract}

B. Bertrand - C. Montagnon · F. Georget · H. Etienne Département des Systèmes Biologiques, UMR-RPB, CIRAD-IRD-UM2, Centre de Coopération Internationale en Recherche Agronomique pour le Développement (CIRAD), 911 Avenue Agropolis, BP 64501, 34394 Montpellier, France

\section{E. Alpizar}

Café Total, AP 129-4050 Alajuela, Costa Rica

L. Lara

ECOM Coffee Group - Nicaragua. Rotonda Jean Paul Geani, $300 \mathrm{~m}$ abajo. Edificio San Marino,

Managua, Nicaragua

R. SantaCreo

Instituto Hondureño del Café (IHCAFE),

AP 3174 Tegucigalpa, Honduras
In the agroforestry system, the mean yield of hybrids was $58 \%$ higher than that of the American cultivars, while the mean yield of hybrids in the full-sun system was $34 \%$ higher. Coffee-based agroforestry systems (AS) are considered effective in protecting the environment in the volcanic cordilleras of Central America. We found that introducing hybrids in coffee-based AS can considerably increase productivity. This finding could be a convincing argument to encourage coffee growers who have adopted the full-sun cropping system to return to agroforestry cropping systems. Finally, the conditions for large-scale dissemination of those new hybrids-which represent a major innovation for C. arabica cropping-was analysed.

M. Hidalgo

Instituto del Café de Costa Rica (ICAFE),

AP 37-1000 San José, Costa Rica

J. M. Quijano

Fundación Salvadoreña para la investigación del Café (PROCAFE), AP 23 Santa Tecla, El Salvador

B. Bertrand $(\square)$

CIRAD, UMR RPB, 34398 Montpellier, France

e-mail: benoit.bertrand@cirad.fr 
Keywords Coffee - Hybrids - Productivity · Ecological innovation · Agroforestry system

\section{Introduction}

Arabica coffee is the main source of export earnings for numerous countries. Latin America is the main area of production of this commodity, which accounts for $80 \%$ of the world export volume. In Central America, coffee was traditionally grown in agroforestry systems (AS) under forest or planted trees. The cropping practices evolved through a series technical advances that were implemented in the 1950s and 1960s, thus creating ideal conditions for a veritable Green Revolution. A switch was made from an extensive AS to an unshaded intensive system with abundant fertilizer (notably 150-300 units of N/ha) and pesticide inputs. This boosted yields from 150 to $1,000 \mathrm{~kg} / \mathrm{ha}$ of green coffee to more than 1,000-1,500 kg, notably in Costa Rica and Colombia. However, in many countries (Andean America, Honduras, El Salvador, Nicaragua, Guatemala and the Chiapas region of Mexico), most coffee growers have not abandoned the AS (Fig. 1).

Coffea arabica is an autogamous species. Growers in Latin America currently have the choice between two types of homozygous lines propagated by seed: American traditional cultivars (Bourbon, Typica, Caturra, Catuai) and Catimor cultivars. These recent latter cultivars are derived from cv. Hibrido de Timor, which is a natural cross between $C$. arabica $(4 \mathrm{n}=2 \mathrm{x}=44)$ and $C$. canephora $(2 \mathrm{n}=2 \mathrm{x}=22)$. C. arabica $(4 \mathrm{n}=2 \mathrm{x}=44)$ and $C$. canephora $(2 \mathrm{n}=2 \mathrm{x}=22)$. The majority of cultivars 'Catimors' have shown complete resistance to all physiological races of the coffee leaf rust (Hemileia vastatrix). He we refer to this seed-propagated material as American cultivars or lines.

Since 1997, coffee growers throughout Central America have had access to some F1 hybrid clones micropropagated by somatic embryogenesis (EtienneBarry et al. 1999; Etienne 2005). These new hybrids, derived from crosses between wild Sudan-Ethiopian and American traditional cultivars or Catimor cultivars, have considerably increased the narrow genetic base of coffee trees cultivated in Latin America. We refer to this material as 'hybrids', while keeping their inter-origin genetic background in mind. In controlled trials conducted in three environments in Costa Rica and Nicaragua, the heterosis found in hybrid populations relative to the parental material was $20-50 \%$ (Bertrand et al. 2005). In sensory evaluations in which the hybrids were compared with traditional lines under various soil-climate conditions, the hybrids performed as well as or better than the traditional lines (Bertrand et al. 2006). As coffee rust resistance genes are dominant, when hybrids are derived from a cross between a rust-resistant Catimor parent and an Ethiopian accession, they will have the same level of resistance as the Catimor parent.

Coffee growers who have adopted Green Revolution principles are aware of the need to crop their coffee in AS as they did in the past, but this can result in an estimated $20-40 \%$ drop in productivity (Vaast et al. 2006). Otherwise, growers who have not abandoned AS, strive to increase the profitability of AS by generating income for ecological service provision, adopting commercial strategies based on better beverage quality, etc. (Vaast and Harmand 2002). Strangely enough, breeding has been overlooked in this wave of innovations for improving AS, although the Green
Fig. 1 Illustration of the C. arabica network trials. a Full-sun system and b agroforestry system
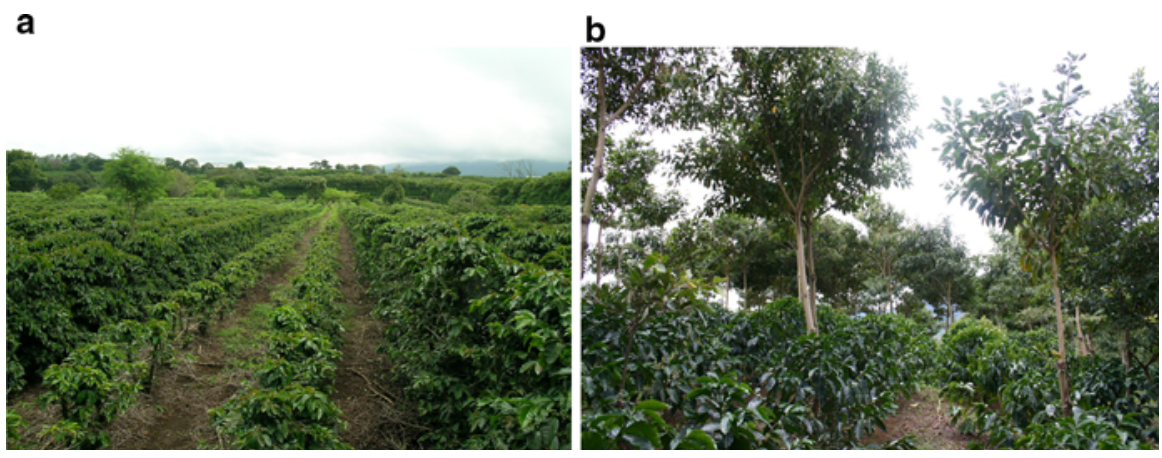
Revolution has been largely based on breeding. The present study was carried out to assess whether introducing new hybrid coffee cultivars in coffeebased AS in Central America would increase cropping system productivity and therefore enhance the profitability of AS. We analyzed the yield performance of these new hybrids in agroforestry (shade) and full-sun (unshaded) cropping systems in comparison with the highest yielding American pure line cultivars distributed in Central America.

\section{Materials and methods}

Plant material

Two types of coffee cultivar were tested in the network:

- Thirteen lines (i.e. American cultivars): namely Caturra, Pacas, Catuai and Bourbon as traditional cultivars, and CR95 (also called Lempira), Catisic, Iapar59, T5296, T17931, T17933, T18121, $\mathrm{T} 18138$ and T18141 as Catimor cultivars.

- Twenty-one $C$. arabica F1 hybrids: crosses of American cultivars with Ethiopian accessions (ET6, ET15, ET25, E41, E416, E531, Anfilo and Rume Sudan).
The hybrids were micropropagated via somatic embryogenesis (see Fig. 2), as previously described (Etienne 2005).

\section{Field trials}

The tests were carried out from 2000 to 2006 in a network of 15 trials (i.e. locations) set up in 1999, 2000, and 2001 in three Central American countries. A randomized block design was used in each trial. Inside each block, cultivars were grown in unit plots of 10 trees. The main trial characteristics and the genotype replications in the 15 trials are summarized in Tables 1 and 2, respectively.

The trials were set up on farms of various sizes (5-150 ha). The elevation of the farms ranged from 750 to $1,580 \mathrm{~m}$ a.s.l. Unlike many multi-site trial networks, we considered that comparisons of new germplasm with traditional cultivars should not involve a change in growers' cropping practices. We thus decided to allow plot managers to make decisions according to their experience and resources. In Costa Rica, the trials were mostly managed in an unshaded intensive system, apart from two lowaltitude trials managed with coffee trees growing under slight shade from Erythrina poeppigina at a density of 150-200 trees/ha. In El Salvador and Honduras, the trials were managed in AS with shade
Fig. 2 Illustration of the coffee somatic embryogenesis micropropagation process under industrial conditions (Nicaragua, CIRAD-ECOM project). a, b Multiplication of embryogenic suspensions in Erlenmeyer flasks; c mass regeneration in temporary immersion bioreactors of directly acclimatizable pregerminated somatic embryos; d plant hardening in the nursery before field transfer
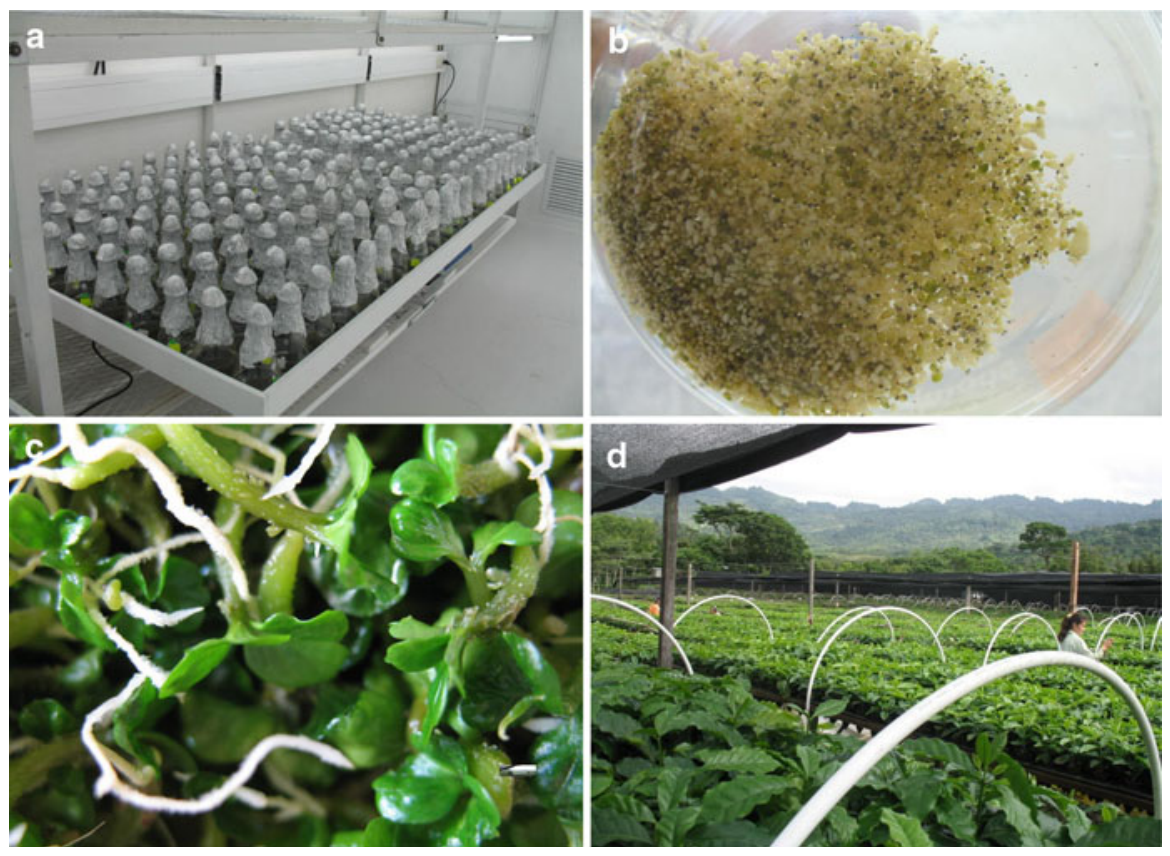


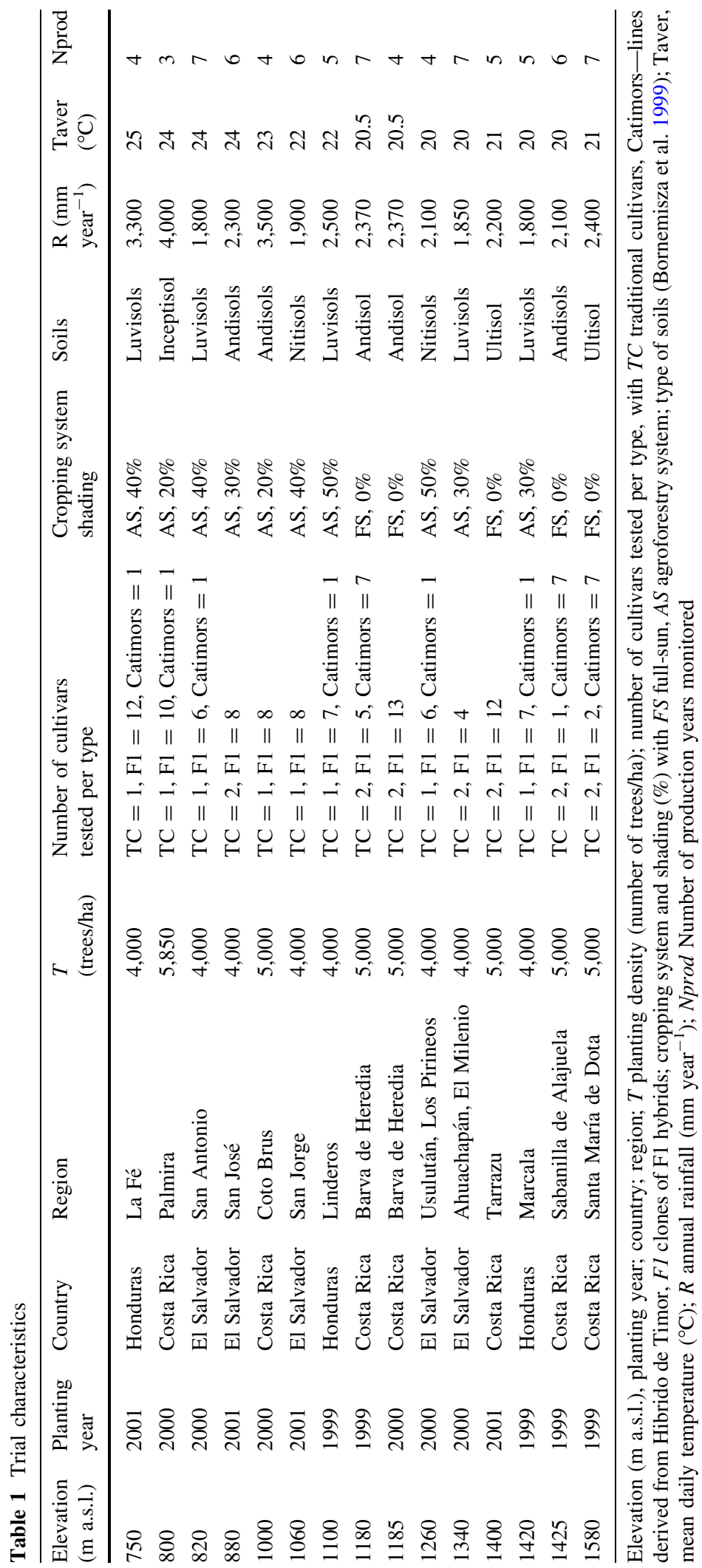


Euphytica (2011) 181:147-158

151

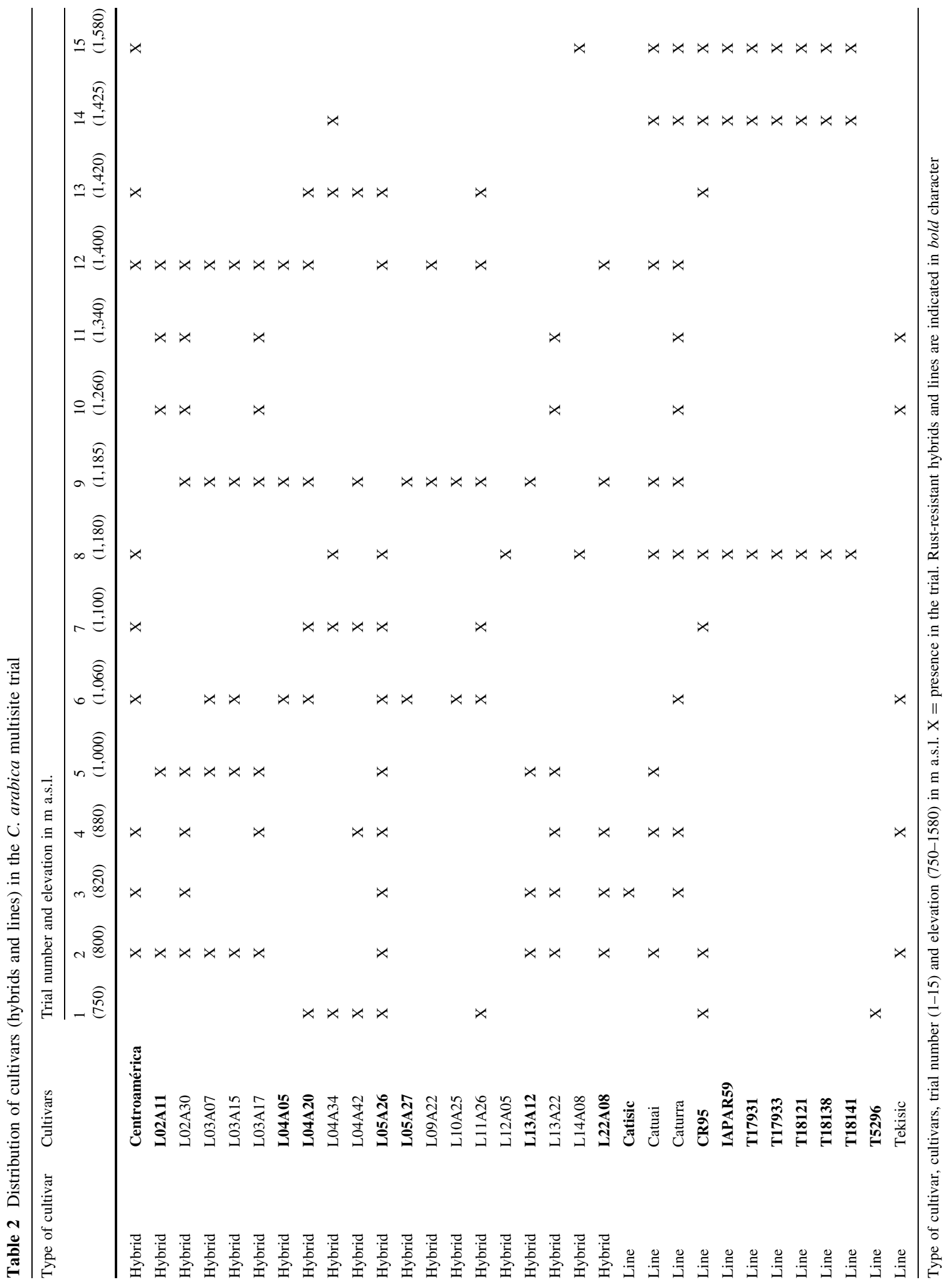

An Springer 
provided by Inga edulis (200-300 trees/ha), sometimes with a few tall native trees such as Cordia alliodora, Juglans steyermarkii and Quercus costaricensis. The shade levels varied between trials and within each plot depending on the season. They were estimated visually at between 20 and $50 \%$. The coffee tree planting density ranged from 4000 to 5,800 trees/ $\mathrm{ha}^{-1}$. In Costa Rica, the plants received [250-350], [200-300], [20-50] kg/ha ${ }^{-1} / \mathrm{year}^{-1}$ of $\mathrm{N}, \mathrm{K}_{2} \mathrm{O}$ and $\mathrm{P}_{2} \mathrm{O}_{5}$, respectively, along with $2-4$ yearly applications of copper hydroxide or triazole to control leaf diseases (coffee leaf rust and brown eye spot). In Honduras and El Salvador, the plants received [50-100], [50-100], [0-20] kg/ha ${ }^{-1} / \mathrm{year}^{-1}$ of $\mathrm{N}, \mathrm{K}_{2} \mathrm{O}$ and $\mathrm{P}_{2} \mathrm{O}_{5}$, respectively, along with zero or two yearly applications of copper hydroxide to control coffee leaf rust.

Traits observed

The traits monitored were average production during the first production cycle before pruning and coppicing. The number of harvests during the first production cycle varied depending on the elevation, degree of intensification, and soil-climate conditions. Table 1 shows the number of production years monitored per trial. These harvests were measured in grams of fresh berries and then expressed in grams of green coffee per tree based on the assumption that the weight of green coffee amounted to $20 \%$ of the fresh berry weight. To facilitate comparisons between trials, we calculated $\mathrm{Y}$ (yield), i.e. the ratio of the sum of harvests (CUM) to the number of harvests. $\mathrm{Y}$ is expressed in grams of green coffee per tree and per year. Two other variables were calculated: earliness (E), which represented the percentage of the first harvest (Y1) over CUM, and the coefficient of variation for the harvests (cvY\%), i.e. the ratio between the standard deviation of CUM and Y.

Data analysis

The SAS System for Windows V9.1 was used for all statistical analyses. Within-location and multi-location analyses of variance were performed on data gathered in the 15 trials. For each trial, we compared lines to hybrids by ANOVA followed by a Newman and Keul's test at $P \leq 0.05$ for $\mathrm{Y}, \mathrm{E}$, and cvY\%. A two-way ANOVA (referred as multi-location analysis), where trials (locations) and types of cultivar (i.e. hybrids vs. lines) were considered as fixed effects, was performed to study interactions between the type of cultivar and the locations. For this two-way ANOVA, yield (Y), earliness (E) and production stability (cvY\%) were studied. Hybrid stability was compared to line stability by a joint regression analysis on locations (Eberhart and Russel 1966).

In a second analysis, a particularly productive hybrid (cv. Centroamerica) with interesting sensory characteristics (data not shown) was compared with the most productive line in each trial for $\mathrm{Y}, \mathrm{E}$, and cvY\%. This hybrid was present in nine trials. As above, a multi-location analysis was carried out for $\mathrm{Y}$ on these nine locations (i.e. trials), using a two-way ANOVA (locations and genotypes considered as fixed effects) followed by a joint regression analysis on locations.

Finally, in a third analysis, we estimated $\mathrm{Y}$ according to the cropping system. We used a nested model as follows:

$\mathrm{Y}_{\mathrm{ijk}}=\mu+\mathrm{v}_{\mathrm{i}}+\mathrm{S}_{\mathrm{k}}+\mathrm{B}_{\mathrm{j} \mid \mathrm{k}}+\mathrm{a}_{\mathrm{l}}+\mathrm{v}_{\mathrm{i}} * \mathrm{a}_{\mathrm{l}}+\mathrm{E}_{\mathrm{ijkl}}$

where $\mathrm{Y}$ is the yield, $\mu$ is the overall mean, $v_{i}$ represents the fixed effect of the type of cultivar i (i.e. hybrid mean vs. line mean), $S_{k}$ represents the random effect of location $S_{k}, B_{j k k}$ is the random effect due to the jth block within location $\mathrm{k}, \mathrm{a}_{1}$ represents the fixed effect of the cropping system (i.e. agroforestry system vs full-sunlight system), $v * \mathrm{a}_{\mathrm{il}}$ represents the random interaction between the type of cultivar $\mathrm{i}$ and cropping system 1 , and $E_{\mathrm{ijkl}}$ represents the random error associated with a particular observation.

\section{Results}

Hybrids compared to lines

For each trial, means of lines and hybrids were compared through an analysis of variance, focusing on yield, earliness, and production stability. Hybrids had significantly greater yields than lines at 14 of the 15 trial sites (Table 3). The differences in yield ranged from 8 to $127 \%$ (Table 3 ). At low elevations (750-880 $\mathrm{m}$ a.s.1.), the differences were not uniform, with extremes ranging from 16 to $127 \%$ and a median of $52 \%$ for this group of four trials. At moderate elevation (1,000-1,340 $\mathrm{m}$ a.s.1.), which was the case for most of the coffee areas in Central America, the 
Table 3 Comparison of F1 hybrids with lines in the 15 trials over the first production cycle before coppicing

\begin{tabular}{|c|c|c|c|c|c|c|c|c|c|c|}
\hline $\begin{array}{l}\text { Elevation } \\
\text { (m a.s.1.) }\end{array}$ & $\begin{array}{l}\text { Yhybrids } \\
(\mathrm{g})\end{array}$ & Ylines (g) & $D(\%)$ & PrY & Ehybrids & Elines & PrE & cvY\%hybrids & cvY\%lines & PrcvY\% \\
\hline 750 & 631 & 450 & 40 & 0.04 & 33.4 & 22.6 & NS & 44.6 & 52.6 & NS \\
\hline 800 & 613 & 530 & 16 & 0.0315 & 22.3 & 16.0 & 0.01 & 48.4 & 61.8 & 0.05 \\
\hline 820 & 250 & 152 & 64 & 0.0001 & 0.6 & 0.0 & 0.02 & 70.0 & 94.0 & 0.001 \\
\hline 880 & 409 & 180 & 127 & 0.0001 & 2.0 & 1.5 & NS & 32.7 & 59.8 & 0.000 \\
\hline 1000 & 737 & 472 & 56 & 0.0001 & 21.8 & 7.6 & 0.001 & 62.4 & 89.3 & 0.005 \\
\hline 1060 & 412 & 372 & 11 & 0.0004 & 1.7 & 0.3 & 0.04 & 50.2 & 56.3 & NS \\
\hline 1100 & 357 & 300 & 19 & NS & 20.0 & 9 & NS & 39.6 & 54.5 & NS \\
\hline 1180 & 890 & 718 & 24 & 0.0001 & 1.9 & 0.0 & 0.001 & 52.9 & 51.6 & NS \\
\hline 1185 & 486 & 328 & 48 & 0.0001 & 16.8 & 12.1 & 0.01 & 38.4 & 46.1 & NS \\
\hline 1260 & 243 & 140 & 73 & 0.037 & 5.5 & 0.0 & 0.00 & 29.7 & 57.5 & 0.006 \\
\hline 1340 & 323 & 146 & 121 & 0.0003 & 5.0 & 2.5 & NS & 50.5 & 73.3 & 0.0003 \\
\hline 1400 & 621 & 318 & 95 & 0.001 & 16.5 & 10.5 & 0.001 & 56.1 & 86.6 & 0.0001 \\
\hline 1420 & 602 & 380 & 58 & 0024 & 15.85 & 11.50 & NS & 42.4 & 46.2 & NS \\
\hline 1425 & 855 & 794 & 8 & 0.049 & 11.0 & 10.5 & NS & 49.5 & 55.7 & NS \\
\hline 1580 & 729 & 672 & 8 & 0.022 & 1.8 & 0.7 & 0.01 & 68.2 & 80.3 & 0.02 \\
\hline
\end{tabular}

For each trial, are indicated: the elevation ( $\mathrm{m}$ a.s.1.), the mean annual production of green coffee (Y in $\mathrm{g}$ and expressed per tree) for the mean of F1 hybrids (Yhybrids) and for the mean of lines (Ylines), $D(\%)$ that represents $\left(D=\frac{\text { Yhybrids }- \text { Ylines }}{\text { Ylines }} \times 100\right)$ and PrY is the associated probability of this difference, Ehybrids and Elines are the earliness of yields respectively representing the mean of F1 hybrids and the mean of lines, and PrE is the associated probability of this difference, cvY\%hybrids and cvY\%lines are the coefficients of variation for harvests, respectively for the mean of F1 hybrids and for the mean of lines and PrcvY\% is the associated probability of this difference. $N S$ not significant at $P=0.05$

superiority of the hybrid mean was substantial, ranging from 11 to $121 \%$, with a median of $48 \%$. Lastly, at high elevation ( $\geq 1400 \mathrm{~m}$ a.s.l.), the differences in yield increased from 8 to $95 \%$, with a median of $33 \%$. A two-way ANOVA revealed a highly significant effect of location and of type of cultivar, respectively $(F=69.7, P<0.0001$ and $F=87.5$ and $P<0.0001)$ and a low but significant interaction between the two $(F=2.65, P<0.01)$. There thus was an interaction between type of cultivar and locations, even though the mean square for the interaction (1.33) was lower than that for the locations and type of cultivar ( 34.7 and 44.1, respectively). This significant interaction was due to the different rate of response of hybrids to lines at each site, as shown in Fig. 3. The analysis of interaction by regression slope revealed that the hybrid mean had a non-significant regression coefficient $(R=-0.04 \pm 0.02)$ and that the line mean had a significant regression coefficient $(R=-1.03 \pm 0.09)$.

We measured earliness as an index representing the percentage of the first harvest (Y1) over the cumulation of harvests for the production cycle. The percentages were highly variable between trials, ranging from 0.6 to $33.4 \%$ for the hybrid means and from 0 to $22.6 \%$ for the line means (Table 3). These differences were statistically significant in only nine out of the 15 trials in the network. During the first production year (data not shown), the hybrid mean yield was significantly higher than the line mean yield at all locations.

Regarding the production stability over the production cycle, the coefficients of variation (cvY\%) for the hybrid means ranged from 29 to $70 \%$, whereas the line means ranged from 46 to $94 \%$ (Table 3). The coefficients of variation for hybrids were always lower than those for lines. Nevertheless, the differences were significant at only eight locations. Overall, it appeared that the hybrid means were more stable than the line means, i.e. production differences between years were less marked for hybrids.

The best hybrid compared to the best line

According to data gathered from this trial network and other locations (data not shown), Centroamerica was 
Fig. 3 Comparison of the mean yield of lines and of hybrids in the 15 trials; $(X$ axis: elevations in $\mathrm{m}$ a.s.1., $Y$-axis: yield in green coffee). Two different letters indicate significant differences at $P<0.05$ between hybrids and lines in the same trial (i.e. elevation)

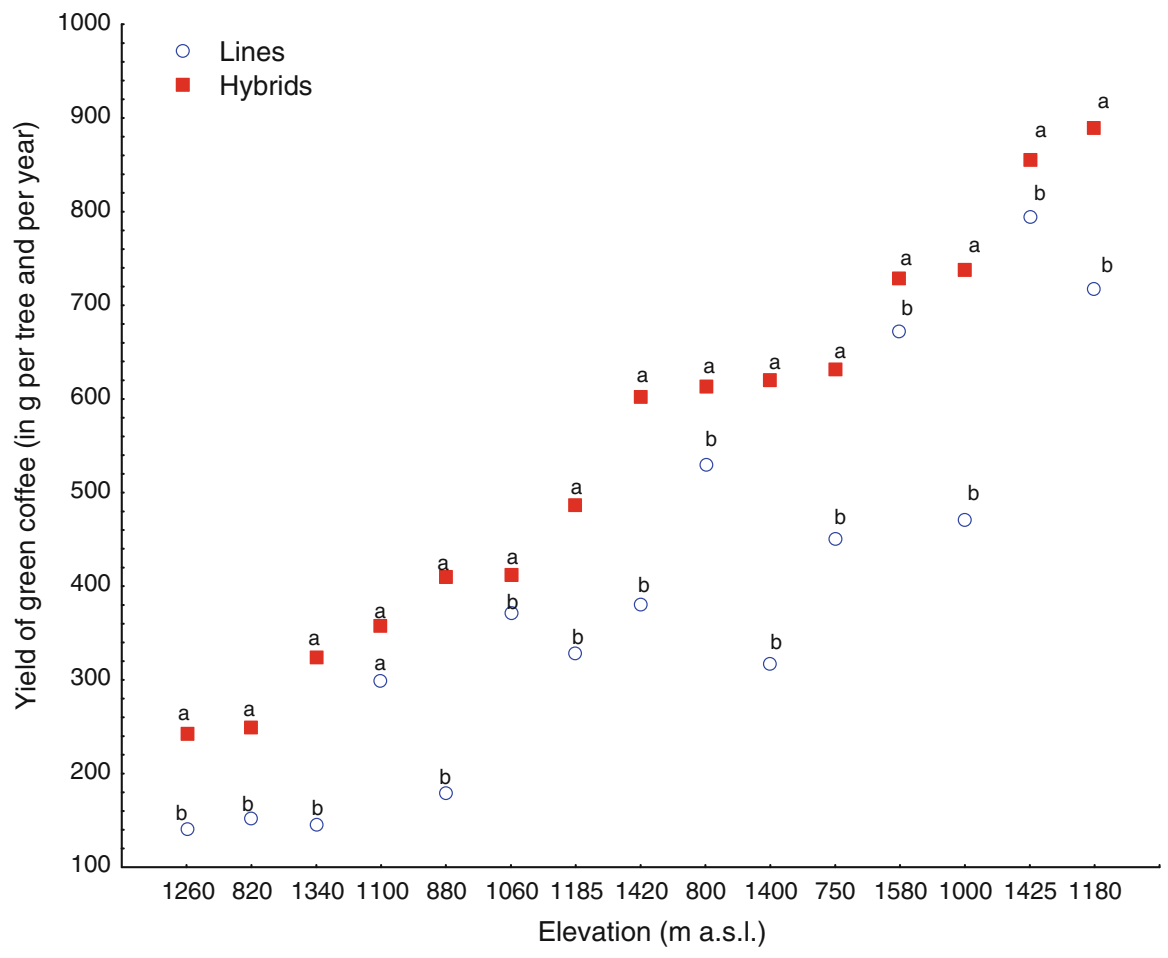

Table 4 Comparison of the best F1 hybrid, cv. Centroamerica with the best line of each trial over the first production cycle

\begin{tabular}{|c|c|c|c|c|c|}
\hline $\begin{array}{l}\text { Elevation } \\
\text { (m a.s.1.) }\end{array}$ & $\begin{array}{l}\text { Yhybrid } \\
\text { 'Centroamérica' (g) }\end{array}$ & $\begin{array}{l}\text { Yline } \\
\text { (best line) (g) }\end{array}$ & $D(\%)$ & PrY & $\begin{array}{l}\text { Name of } \\
\text { the best line }\end{array}$ \\
\hline 800 & 733 & 602 & 21 & 0.03 & CR95 \\
\hline 820 & 265 & 165 & 60 & 0.005 & Catisic \\
\hline 880 & 453 & 186 & 243 & 0.0018 & Pacas \\
\hline 1060 & 560 & 415 & 35 & 0.05 & Pacas \\
\hline 1100 & 460 & 340 & 35 & 0.04 & CR95 \\
\hline 1180 & 938 & 717 & 31 & 0.001 & T17933 \\
\hline 1400 & 660 & 353 & 87 & 0.0008 & Caturra \\
\hline 1425 & 760 & 540 & 41 & 0.03 & CR95 \\
\hline 1580 & 771 & 674 & 14 & NS & IAPAR59 \\
\hline
\end{tabular}

For each trial, are indicated: the elevation (m a.s.1.), the mean annual production of green coffee (Y in $g$ and per tree) for the the F1 hybrid cv. Centroamerica (Yhybrid) and for the best line of the trial (Ylines), $D(\%)$ represents $\left(D=\frac{\text { Yhybrid-Yline }}{\text { Yline }} \times 100\right)$ and PrY is the associated probability of this difference, and the name of the best line per trial. NS not significant at $P=0.05$

the most productive hybrid. This hybrid, which was present in nine trials in the network, was compared to the best line in each of the nine trials, based on the same criteria as above. The best line in each trial is indicated in Table 4. In five trials, a Catimor line was involved. In four trials, traditional cultivars were involved (i.e. Catuai or Caturra). A multi-location analysis revealed a highly significant difference between the best hybrid and the best line $(F=27.3, \operatorname{Pr}<0.0001)$ and a non- significant interaction $(F=1.3, \operatorname{Pr}=0.22)$. Depending on the trial, the hybrid Centroamerica produced from 14 to $243 \%$ more than the best line (Table 4), and the mean estimated difference amounted to $37 \%$. When the analysis was carried out for each location, the differences were significant for eight trials and nonsignificant for one trial. At all locations, the hybrid Centroamerica displayed better earliness than the best line. However, the percentages were highly variable 
between trials, ranging from 0.02 to $22 \%$ for the hybrid and from 0 to $16 \%$ for the line (data not shown). The differences were significant in five of the nine trials.

The multi-location analysis revealed a significant difference between the hybrid and the best line for each trial $(F=8.3, \operatorname{Pr}=0.03)$ and a non-significant interaction $(F=1.5, \operatorname{Pr}=0.07)$. The first year production for the hybrid amounted to $10 \%$ on average of the total for the first production cycle as opposed to $4 \%$ for the best line.

The production stability of the hybrid appeared to be better in the nine trials. The coefficient of variation for the hybrid ranged from 31 to $68 \%$, whereas that of the lines ranged from 45 to $94 \%$. The coefficients of variation for the hybrid were always lower than those for the line. The differences were significant for the nine locations. The multi-location analysis revealed a highly significant difference between the hybrid and the line $(F=3.1, \operatorname{Pr}<0.01)$, and a non-significant interaction $(F=1.4, \operatorname{Pr}=0.06)$. The mean coefficient of variation of the hybrid was $55 \%$ as opposed to $66 \%$ for the line.

Comparison of hybrids and lines according to the cropping system

A mixed-effect analysis of variance was used to estimate yield differences between types of cultivar under the two farming systems. The interaction between farming systems and type of cultivar was highly significant $(F=77.4, P<0.0001)$. In the AS, the mean hybrid yield was $460 \mathrm{~g}^{\text {year }}{ }^{-1}$ of green coffee per tree as opposed to a mean yield of $290 \mathrm{~g} \mathrm{year}^{-1}$ per tree for the lines (Fig. 4). The difference in favor of the hybrid mean was highly significant $(P<0.0001)$ and the yield increase amounted to $58 \%$. In the full-sun system, the mean hybrid yield was estimated at $754 \mathrm{~g}_{\text {year }}^{-1}$ as opposed to $562 \mathrm{~g} \mathrm{year}^{-1}$ for the mean line yield (Fig. 4). The difference in favor of the hybrids amounted $34 \%$ and was highly significant.

\section{Discussion}

In Central America, Arabica coffee can be grown at elevations ranging from 700 to $1,600 \mathrm{~m}$ a.s.1, in fragile mountainous ecosystems. Furthermore, the

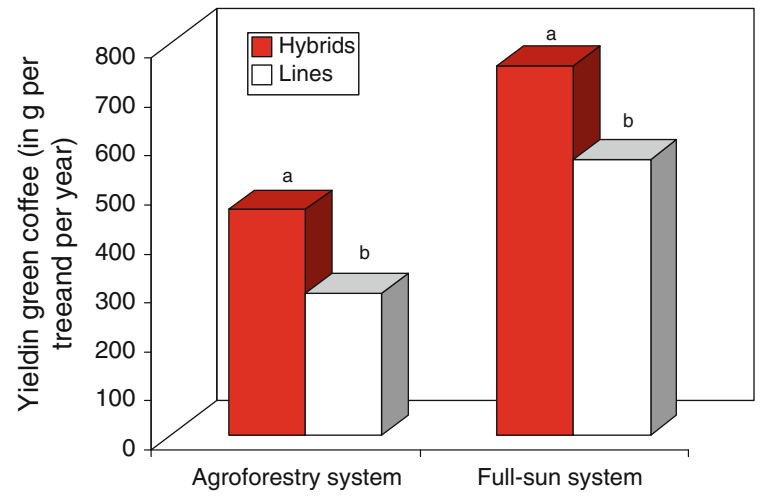

Fig. 4 Comparison of the mean yield of lines and of hybrids according to the cropping system. Two different letters indicate significant differences at $P<0.05$ between cropping systems

coffee-growing area is one of the world hotspots for biodiversity. Coffee agro-forests, with shade trees interspersed amongst the coffee plants, are often the only habitat with remaining tree cover within these areas for migratory birds in the Mesoamerican biological corridor, as almost all forests have been removed at the elevations where coffee is grown (Harmand et al. 2007; Jha and Dick 2008). These AS thus benefit international conservation initiatives. Regarding soil erosion, studies indicate that shade trees can reduce runoff by more than half on coffee slopes via natural litter fall or pruning residues that cover the soil, reduced impact of raindrops, improved soil structure and enhanced infiltration (Beer et al. 1998; Snoeck and Vaast 2009). Furthermore, rural households rely on fuelwood derived from trees in coffee agro-forests. Over the last 40 years, coffee cultivation intensification has led to the loss of more than $50 \%$ of the tree cover (Harmand et al. 2007). This coffee intensification has also resulted in loss of landscape connectivity and extensive loss of biodiversity in many coffee-growing zones, and probably an increase in agrochemical pollution of rivers and aquifers (Babbar and Zak 1995). The large-scale adoption of AS depends on the economic benefits that they can provide growers in various socio-economic and ecological settings. The present study revealed that introducing new intraspecific hybrid cultivars in coffee-based AS of Central America would considerably increase cropping system productivity, while also considerably broadening the narrow genetic base of cultivated $C$. arabica by introducing genetic diversity from wild Ethiopian progenitors. 
The set of trial locations was representative of the range of productive sites in Central American coffeegrowing zone. In this region, temperature mainly varies as a function of the elevation. The network of trials covered the regional elevation range for coffee growing, i.e. from 750 to $1,580 \mathrm{~m}$ a.s.l. With respect to rainfall, in Costa Rica, for example, the trials at Tarrazu and Santa Maria de Dota were under a Pacific climate (relatively low rainfall with a marked dry season). On the other hand, the plot at Palmira was in a very wet zone without any dry season.

The soils in which coffee plants were grown in the trials were representative of three major morphopedological regions of Central America (Bornemisza et al. 1999), according to the 1976 FAO classification. In Costa Rica, these were luvisols or andosols in the basic volcanic highlands of the Tertiary. Such soils are highly suited for coffee growing. In Honduras and part of El Salvador, luvisols of the acid volcanic highlands were involved, derived from sediments of the Tertiary, which are fragile with low fertility. In eastern El Salvador, andosols are formed on the volcanic cordillera of the Quaternary, i.e. excellent soils for coffee growing.

This network of trials was also designed to represent the diversity of cropping systems in Central America, since it consisted of 10 trials in AS and five in full-sun systems. In the latter case, agricultural practices were relatively uniform, particularly with respect to fertilizer applications and pesticide treatments. On the other hand, the AS ranged from very low-input agriculture to intensive coffee growing. As underlined previously, we decided to allow plot managers to make decisions according to their experience and resources. The result was a network of trials with contrasting cropping systems and yields. For example, in El Salvador, the San Antonio trial at $820 \mathrm{~m}$ a.s.l. represented a low-intensity coffee plantation in an AS where no agrochemicals were applied, which probably explains the low yields. Conversely, at 1,420 $\mathrm{m}$ a.s.l., the Sabanilla de Alajuela trial was on a farm that practiced intensive coffee growing, which explains the high yields. Production cycle lengths varied in the network of trials. This variability was linked to soil fertility, temperatures and growers' choices. In the hot, wet lowland climate at Palmira, the trees needed coppicing after 3 years of high yields. In the temperate climate at Santa Maria de Dota (1,580 $\mathrm{m}$ a.s.1.), coffee was produced for
7 years before coppicing. In the very low-intensity, hence low-yield, AS at San Antonio or Ahuachapán in El Salvador, it also took 7 years before the trees needed coppicing, according to the growers' criteria.

With this network set up, it was therefore possible to compare cultivars in contrasting situations representative of the soil-climate conditions and agricultural practices that prevail in Central America. Under these conditions, yield differences between hybrids and lines ranged from 8 to $127 \%$, with a median of $48 \%$ in favor of hybrids. This first result tallies with those obtained in small controlled trials in Latin America and Africa by Walyaro (1983) and Cilas et al. (1998), where hybrids produced between 10 and $200 \%$ more than lines. Based on controlled trials in full sunlight, we previously estimated that heterosis ranged from 22 to $47 \%$ by comparing hybrids with their maternal lines (Bertrand et al. 2005). Here, we compared selected hybrids with traditional or recent lines, it is therefore normal that even greater differences were found between hybrids and lines.

A few trends were also noted that confirmed previous observations. Firstly, hybrids began producing earlier, and they appeared to be more stable over the production cycle and more stable across different environments. Part of the earliness could be explained by heterosis, but also it may have been due to the propagation method used for these hybrids. Indeed, somatic embryogenesis causes some secondary effects that have yet to be clarified and properly measured but which seem to play a role in tissue rejuvenation (Hackett Wesley and Murray John 1993; Perrin et al. 1997). When working with the same genotype, we found that, for nursery coffee plants of the same height, plants derived from somatic embryos were significantly more vigorous than those derived from seeds (Menéndez-Yuffá et al. 2010).

As regards stability, most authors agree that hybrids are more stable than lines (Gallais 2009). In general, heterozygotes are more capable than homozygotes of exploiting a spatiotemporally variable environment. We noted this homeostasis in the coffee hybrids, which led to lower yield variations over the cycle in comparison to the lines. This greater homeostasis in hybrids probably played an important role in the yield stability. As we have already highlighted (Bertrand et al. 2006), hybrids with greater vegetative vigor have higher leaf-to-fruit ratios and a better carbohydrate supply to berries 
than traditional cultivars, which results in a better quality beverage. We therefore conclude that heterosis gave hybrids a true advantage over lines in terms of productivity, but also in terms of yield stability. Moreover, this difference in productivity was not achieved by increasing inputs. A comparison of hybrid means and line means according to cropping systems showed that the yield increase in the agroforestry system amounted to 58\%. This increase, which seems considerable, amounted to $170 \mathrm{~g}$ of green coffee per tree. In the full-sun system, the relative increase was less (34\%), but the difference in green coffee was $190 \mathrm{~g}$. Consequently, the returns on investment with both systems were very similar.

The success of large-scale dissemination of a hybrid cultivar depends on the extent of control over the reproductive system. Somatic embryogenesis has been perfectly technically mastered in Nicaragua. The remaining question concerns economic risks associated with the adoption of this innovation. Investing in hybrid micropropagated plantlets is expensive. The additional cost per tree is currently 0.5-0.6 USD, i.e. an investment of 2,500-3,000 USD/ ha. However, we believe that hybrid cultivars would be more cost-effective at this price. A recent study of ECOM-INCAE (data not shown) indicated that renovating AS with hybrid plants is better than with traditional cultivars. After 6 years, the difference in net present value between hybrids and traditional cultivars was found to be more than 5,000 USD/ha.

In Green Revolution systems geared towards high production, irrational use of hybrids can worsen the ecological footprint. As with any innovation, thought will have to be given to the ecological sustainability of intensive farms. In AS, such adoption will have to be facilitated by credit policies, and especially by minimum intensification policies, notably with respect to input use. In addition, the investment rationale must come with a commercial policy to capture new lucrative markets.

Acknowledgments This work was financed by FONTAGRO (www.fontagro.org). We thank the administrative staff of PRO MECAFE, PROCAFE, ICAFE, and IHCAFE for assistance.

Open Access This article is distributed under the terms of the Creative Commons Attribution Noncommercial License which permits any noncommercial use, distribution, and reproduction in any medium, provided the original author(s) and source are credited.

\section{References}

Abbar LI, Zak DR (1995) Nitrogen cycling in coffee agrosystems: net $\mathrm{N}$ mineralization in the presence or absence of shade trees. Agric Ecosyst Environ 48:107-113

Beer J, Muschler R, Kass D, Somarriba E (1998) Shade management in coffee and cacao plantations. Agrofor Syst 38:139-164

Bertrand B, Etienne H, Cilas C, Charrier A, Baradat P (2005) Coffea arabica hybrid performance for yield, fertility and bean weight. Euphytica 141:255-262

Bertrand B, Vaast P, Alpizar E, Etienne H, Davrieux F, Charmetant P (2006) Comparison of bean biochemical composition and beverage quality of arabica hybrids involving Sudanese-Ethiopian origins with traditional varieties at various elevations in Central America. Tree Physiol 26:1239-1248

Bornemisza E, Collinet J, Segura A (1999) Los suelos cafetaleros en América Central y su fertilización. In: Bertrand B, Rapidel B (eds) Desafios de la caficultura en Centroamérica. IICA, San José, Costa Rica, pp 97-138

Cilas C, Bouharmont P, Boccara M, Eskes AB, Baradat $\mathrm{P}$ (1998) Prediction of genetic value for coffee production in Coffea arabica from a half-diallel with lines and hybrids. Euphytica 104:49-59

Eberhart SA, Russel WA (1966) Stability parameters for comparing varieties. Crop Sci 6:36-40

Etienne H (2005) Protocol of somatic embryogenesis: coffee (Coffea arabica L. and C. canephora P.). In: Jain SM Gupta PK (eds) Protocols for somatic embryogenesis in woody plants. Series: Forestry sciences, vol 77. Springer, The Netherlands, Hardcover, pp 167-179, ISBN: 1-40202984-5

Etienne-Barry D, Bertrand B, Vasquez N, Etienne H (1999) Direct sowing of Coffea arabica somatic embryos massproduced in a bioreactor and regeneration of plants. Plant Cell Rep 19:111-117

Gallais A (2009) Heterosis et variétés hybrides en amélioration des plantes. Ed Quae, Versailles, France

Hackett Wesley P, Murray John R (1993) Maturation and rejuvenation in woody species. In: Ahuja MR (ed) Micropropagation of woody plants. Kluwer, Dordrecht, pp 93-105, ISBN 0792318072, 97807922318071

Harmand JM, Avila H, Dambrine E, Skiba U, De Miguel S, Renderos Duran RV, Oliver R, Jimenez F, Beer J (2007) Nitrogen dynamics and soil nitrate retention in a Coffea arabica-Eucalyptus deglupta agroforestry system in southern Costa Rica. Biogeochemistry 85:125-139

Jha S, Dick CW (2008) Shade coffee farms promote genetic diversity of native trees. Curr Biol 18-24:1126-1128

Menéndez-Yuffá A, Barry-Etienne D, Bertrand B, Georget F, Etienne H (2010) A comparative analysis of the development and quality of nursery plants derived from somatic embryogenesis and from seedlings for large-scale propagation of coffee (Coffea arabica L.). Plant Cell Tiss Organ Cult 102(3):297-307

Perrin Y, Doumas P, Lardet L, Carron MP (1997) Endogenous cytokinins as biochemical markers of rubber-tree (Hevea brasiliensis) clone rejuvenation. Plant Cell Tiss Organ Cult 47:239-245 
Snoeck D, Vaast P (2009) Importance of organic matter and biological fertility in coffee soils. In: Wintgens JN (ed) Coffee-growing and processing, 2nd edn. Wiley VCH, Germany

Vaast P, Harmand JM (2002) The importance of agroforestry systems for coffee production in Central America and Mexico. In: CIRAD-CP (ed) Recherche et caféiculture. Montpellier, pp 34-43
Vaast P, Perriot JJ, Guyot B, Génard M (2006) Fruit thinning and shade improve bean characteristics and beverage quality of coffee (Coffea arabica L.) under optimal conditions. J Sci Food Agric 86:197-204

Walyaro DJ (1983) Considerations in breeding for improved yield and quality in arabica coffee (Coffea arabica L.). Doctoral Thesis, Agricultural University, Wageningen 